\title{
Effect of Cassava mill effluent on some soil chemical properties and the growth of fluted pumpkin (Telfairia occidentalis Hook F.)
}

\section{Ehi Robert Orhue,* Enogiomwan Esther Imasuen and Daniel Enuenweyoi Okunima}

\author{
Department of Soil Science, Faculty of Agriculture, University of Benin, Benin City, NIGERIA
}

*Corresponding author. E-mail: orhuerob@yahoo.com

Received: June 19, 2014; Revised received: August 10, 2014 ; Accepted: August 30, 2014

\begin{abstract}
In the trials, Cassava mill Effluent was used for fluted pumpkin (Telfairia occidentalis) cultivation in order to verify the influence of the effluent on the growth and some soil chemical properties. In this regard, a completely randomized and randomized complete block designs were used in the greenhouse and field trials respectively with 6 treatments replicated 3 times. In the greenhouse, the following rates of $0,100,200,300,400$ and $500 \mathrm{ml}$ per $5 \mathrm{~kg}$ topsoil were used while in the field trial, 0, 40000, 80000, 120000, 160000 and 200000 litres/ha were utilized. The rates used in the field were equivalent to those of greenhouse. In both trials, the cassava mill effluent was applied 2 weeks prior to transplanting the seedlings. Results indicated that the cassava mill effluent significantly $(P<0.05)$ increased soil pH, organic carbon, N, P, K, Ca, Mg, Na, Fe, Cu and Zn whereas the exchangeable acidity decreased significantly $(\mathrm{P}<0.05)$ with corresponding increase in cassava mill effluent treatments. Except $\mathrm{N}$ and $\mathrm{Na}$, which declined with corresponding increase in the cassava mill effluent treatments, an improved $\mathrm{P}, \mathrm{K}, \mathrm{Mg}, \mathrm{Ca}, \mathrm{Fe}, \mathrm{Cu}$ and $\mathrm{Zn}$ components was achieved in cassava mill effluent polluted plants compared to control. The plant height, significantly $(P<0.05)$ decreased with increased cassava mill effluent treatment in the greenhouse trial while in the field trial, 120000 litres/ha was significantly $(P<0.05)$ higher than other treatments. In the greenhouse trial, significantly $(P<0.05)$ higher number of leaves was attained in $100 \mathrm{ml}$ treatment compared to other treatments whereas in the field trial, the 120000 and 200000 litres/ha were significantly $(P<0.05)$ higher compared to other treatments
\end{abstract}

Keywords: Effluent, Fluted pumpkin, Growth, Pollution, Soil properties, Treatments

\section{INTRODUCTION}

Cassava (Manihot esculentus Crantz) is widely cultivated in the tropical and subtropical regions of the world and it produces starchy tuberous roots with more than 200 calories/day of food value (FAO, 2004). Cassava is a staple food of nearly one billion people in Africa, South America, Asia and Pacific (ANU, 2007). In Nigeria, the estimated cassava production is approximately over 34 million metric tons (FAO, 2004) and a lot of trade is associated with the processing of the tubers. The cassava tuber consists of peel and flesh with significant hydrocyanic acid which is hazardous to mankind and for use as human food, the peel is invariably removed and only the flesh is utilized (Olorunfemi et al., 2008). Before consumption, by man the fleshy part of the tuber has to be severally detoxified. During the detoxification, a lot of effluent and solid wastes are generated and released into the environment. One of the major recipients of this effluent is the soil. The disposal of this cassava effluent is a source of concern to Environmentalists. Horsfall et al. (2006) and Isabirye et al. (2007) estimated that an average $2.62 \mathrm{~m}^{3}$ ton $^{-1}$ of solid residue and $3.68 \mathrm{~m}^{3}$ ton $^{-1}$ water residues are generated via cassava processing in Nigeria.

ISSN : 0974-9411 (Print), 2231-5209 (Online) All Rights Reserved @ Applied and Natural Science Foundation www.ansfoundation.org
Ogboghodo et al. (2003) reported that soil treated with cassava mill effluent exhibited an increase in $\mathrm{pH}, \mathrm{P}, \mathrm{K}$, $\mathrm{Mg}, \mathrm{Ca}$ and $\mathrm{Na}$. Akpan et al. (2011) also reported increased $\mathrm{pH}, \mathrm{N}$, organic carbon, exchangeable acidity and decreased $\mathrm{Mg}, \mathrm{K}, \mathrm{P}$ in soil treated with cassava mill effluent. It was recorded by Olorunfemi et al (2008) that cassava mill effluent inhibited seed germination, the growth as well as chlorophyll content of maize and sorghum crops. Also, Olorunfemi et al (2011) reported malformed root length, induced chromosome aberration in the root cell of onion plant seedlings assayed in cassava mill effluent while Ogboghodo et al, (2003) has recorded a decrease in maize height with increased volume of cassava mill effluent treatment.

The fluted pumpkin is commonly cultivated and consumed in Nigeria because of its nutritive value. This leafy and fruit vegetable growth is always boosted with farmyard manure and where available, an inorganic fertilizers such as N P K are used. The Cassava mill effluent is commonly available in Nigeria especially in Southern part of the country. Therefore, the purpose of this study was to determine the influence of Cassava mill effluent on some soil chemical properties and growth of fluted pumpkin (Telfairia occidentalis). 


\section{MATERIALS AND METHODS}

The greenhouse and field trials were conducted at the experimental site of the Faculty of Agriculture, University of Benin, Benin City which lies between longitude $5^{\circ}$ $38^{\prime} 52^{\prime} \mathrm{E}$ and latitude $6^{\circ} 24^{\prime} 20.9^{\prime} \mathrm{N}$.. The rainy season is between April and September with a peak at June while the dry season is between October and March. The average relative humidity and temperature is $70 \%$ and $27^{\circ} \mathrm{C}$ respectively.

Greenhouse trial: The topsoil collected from a depth of $0-15 \mathrm{~cm}$ at a plot left fallow for about 5 years was air-dried and sieved to remove debris. Thereafter, $5 \mathrm{~kg}$ sieved soil was filled into the polythene bags. Each polythene bag was placed on a saucer to prevent inter replicate contamination. The trial was laid out in completely randomized design and replicated 3 times. Six levels of cassava mill effluent namely 0, 100, 200, 300,400 and $500 \mathrm{ml}$ per $5 \mathrm{~kg}$ soil were applied to the polythene 2 weeks before transplanting one seedling per pot to allow for the cassava effluent mineralization and equilibration. Three pots per treatment were used. Therefore, each replicate had 18 pots while the entire greenhouse trial had 54 polythene bags. The greenhouse trial lasted for 56 days. Thereafter, data on the height and number of leaves were taken. After data collection, the plants were carefully uprooted, the shoot carefully separated from the root, oven-dried at $78^{\circ} \mathrm{C}$ for 48 hours to a constant weight used in determining the nutrient content of the plant.

Field trial: The field trial which was organised in a randomized complete block design with 3 replicates occupied an area measuring $12 \mathrm{~m} \times 10 \mathrm{~m}$. Each replicate had 6 beds and each bed with a dimension of $2 \mathrm{~m} \times 2 \mathrm{~m}$ represented a treatment. The replicates were separated from one another by $1 \mathrm{~m}$ alley while the beds were separated from one another by $50 \mathrm{~cm}$ alley. The moistened beds were treated with the following rates of cassava mill effluent: 0, 40000, 80000, 120000, 160000 and 200000 litres /ha. These rates were equivalent to those of greenhouse trial. The applied cassava mill effluent was thoroughly mixed with the soil and left for 2 weeks before transplanting 4 seedlings per bed at a spacing of $90 \mathrm{~cm} \times 90 \mathrm{~cm}$. This field trial also lasted for 56 days. The data collected were similar to that of greenhouse trial.

Effluent and soil analysis: The Cassava mill effluent was analysed prior to application while the soil used was analysed before and after the trials. The cassava mill effluent $\mathrm{pH}$ was read directly by glass electrode $\mathrm{pH}$ meter while the soil $\mathrm{pH}$ was determined at a soil to water ratio of 1: 1 using a glass electrode $\mathrm{pH}$ meter. The N, P, K, Mg, Ca, Na, Fe Zn and Cu content of the cassava mill effluent were determined by methods of Ademoroti (1996) whereas the sand, silt, clay, organic carbon, $\mathrm{N}, \mathrm{P}, \mathrm{K}, \mathrm{Mg}, \mathrm{Ca}, \mathrm{Na} \mathrm{Ea}, \mathrm{Fe}, \mathrm{Cu}$ and $\mathrm{Zn}$ components of the soil were determined by methods of Udo et al. (2009).

Plant analysis: The oven-dried plant materials were ground and then digested with a mixture of concentrated $\mathrm{HNO}_{3}, \mathrm{H}_{2} \mathrm{SO}_{4}$ and $\mathrm{HCIO}_{4}$ acids (IITA, 1979). The Na, $\mathrm{K}, \mathrm{Ca}, \mathrm{Fe}, \mathrm{Cu}$ and $\mathrm{Zn}$ were read by UNICAM 969 Atomic Absorption Spectrophotometer. Udo et al (2009) method was used for P determination while the micro-Kjeidhal method of Jackson (1962) was adopted for $\mathrm{N}$ determination. The data obtained were analysed by Genstat statistical version 6. 1. 234 (Payne, 2002). Mean separation was carried out by Duncan multiple range test at $5 \%$ level of probability.

\section{RESULTS AND DISCUSSION}

Properties of Cassava mill effluent used: Table 1 shows the properties of the cassava mill effluent used. The cassava mill effluent has a foul odour and unattractive sight. It is acidic and contains both suspended and dissolved particles, $\mathrm{N}, \mathrm{P}, \mathrm{K}, \mathrm{Mg}, \mathrm{Ca}$, $\mathrm{Na}, \mathrm{Fe}, \mathrm{Cu}$, and $\mathrm{Zn}$.

Pre-trial soil properties: The pre-trial soil properties of both trials are shown in Table 2 . The soil was acidic with low nutrient components. The organic carbon, N,

Table 1. Properties of the Cassava mill effluent used.

\begin{tabular}{|c|c|c|}
\hline Parameters & & Value \\
\hline$\overline{\mathrm{pH}}$ & 4 & 5.07 \\
\hline $\mathrm{N}$ & & 0.19 \\
\hline $\mathrm{P}$ & & 0.18 \\
\hline K & & 0.58 \\
\hline $\mathrm{Mg}$ & & 0.82 \\
\hline $\mathrm{Ca}$ & $\mathrm{mgl}^{-1}$ & 1.48 \\
\hline $\mathrm{Na}$ & & 1.20 \\
\hline $\mathrm{Fe}$ & & 2.00 \\
\hline $\mathrm{Cu}$ & & 1.83 \\
\hline $\mathrm{Zn}$ & & 1.07 \\
\hline Total dissolved solids & & 766 \\
\hline Total suspended solids & & 789 \\
\hline
\end{tabular}

Table 2. Physico-chemical properties of the soils used in the trials.

\begin{tabular}{lcc}
\hline Properties & Greenhouse value & Field value \\
\hline $\mathrm{pH}$ & 5.50 & 5.40 \\
Organic carbon $(\mathrm{g} / \mathrm{kg})$ & 2.25 & 2.07 \\
$\mathrm{~N}(\mathrm{~g} / \mathrm{kg})$ & 0.95 & 0.82 \\
$\mathrm{P}(\mathrm{mg} / \mathrm{kg})$ & 1.50 & 1.32 \\
$\mathrm{~K}(\mathrm{cmol} / \mathrm{kg})$ & 0.11 & 0.12 \\
$\mathrm{Mg}(\mathrm{cmol} / \mathrm{kg})$ & 0.12 & 0.14 \\
$\mathrm{Ca}(\mathrm{cmol} / \mathrm{kg})$ & 0.10 & 0.12 \\
$\mathrm{Na}(\mathrm{cmol} / \mathrm{kg})$ & 0.08 & 0.10 \\
$\mathrm{Fe}(\mathrm{mg} / \mathrm{kg})$ & 1.20 & 1.15 \\
$\mathrm{Cu}(\mathrm{mg} / \mathrm{kg})$ & 0.06 & 0.05 \\
$\mathrm{Zn}(\mathrm{mg} / \mathrm{kg})$ & 0.76 & 0.56 \\
$\mathrm{Sand}(\mathrm{g} / \mathrm{kg})$ & 849 & 850 \\
Silt $(\mathrm{g} / \mathrm{kg})$ & 37 & 35 \\
$\mathrm{Clay}(\mathrm{g} / \mathrm{kg})$ & 114 & 115 \\
\hline
\end{tabular}


Ehi Robert Orhue et al. / J. Appl. \& Nat. Sci. 6 (2): 320-325 (2014)

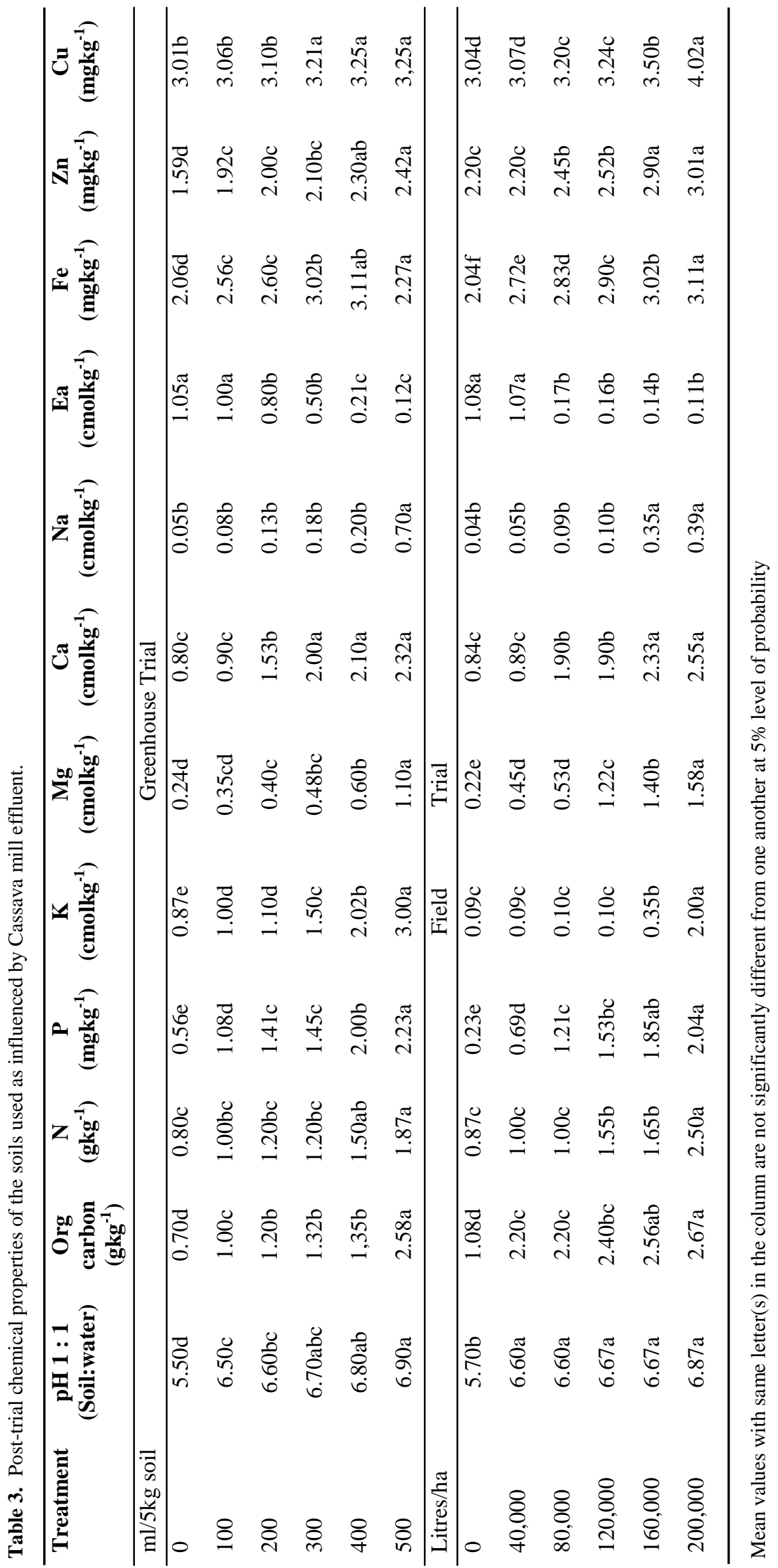


Ehi Robert Orhue et al. / J. Appl. \& Nat. Sci. 6 (2): 320-325 (2014)

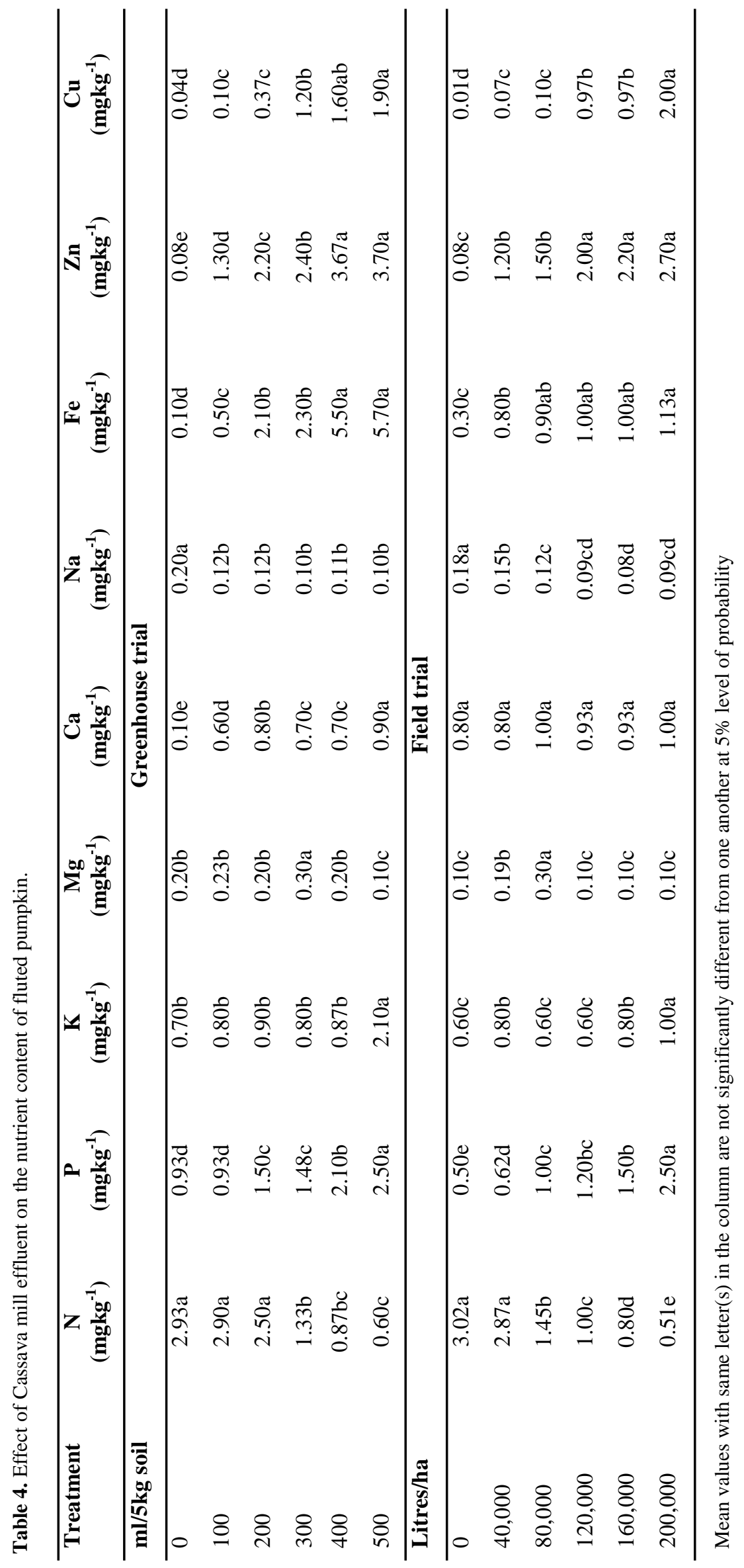


Table 5. Influence of Cassava mill effluent on plant height and number of leaves of fluted pumpkin.

\begin{tabular}{lcc}
\hline Treatment & $\begin{array}{c}\text { Plant height } \\
(\mathbf{c m})\end{array}$ & Number of leaves \\
\hline ml/5 kg soil & \multicolumn{2}{c}{ Greenhouse trial } \\
\hline 0 & $101.33 \mathrm{a}$ & $29.33 \mathrm{c}$ \\
100 & $99.67 \mathrm{a}$ & $34.67 \mathrm{a}$ \\
200 & $94.34 \mathrm{~b}$ & $32.67 \mathrm{~b}$ \\
300 & $50.67 \mathrm{c}$ & $33.00 \mathrm{~b}$ \\
400 & $50.33 \mathrm{c}$ & $29.00 \mathrm{c}$ \\
500 & $47.33 \mathrm{c}$ & $23.33 \mathrm{~d}$ \\
\hline Litres/ha & Field & Trial \\
\hline 0 & $103.80 \mathrm{c}$ & $57.30 \mathrm{~d}$ \\
40,000 & $108.70 \mathrm{bc}$ & $62.00 \mathrm{~cd}$ \\
80,000 & $105.00 \mathrm{c}$ & $67.00 \mathrm{bc}$ \\
120,000 & $127.20 \mathrm{a}$ & $76.00 \mathrm{a}$ \\
160,000 & $111.00 \mathrm{bc}$ & $64.00 \mathrm{~cd}$ \\
200,000 & $119.20 \mathrm{ab}$ & $74.00 \mathrm{ab}$ \\
\hline
\end{tabular}

Mean values with same letter(s) in the column are not significantly different from one another at $5 \%$ level of probability

$\mathrm{P}, \mathrm{K}, \mathrm{Mg}, \mathrm{Ca}$, and $\mathrm{Cu}$ for example were below the critical values of 20-30 $\mathrm{mgkg}^{-1}$ (Enwezor et al., 1989), 1.5-2.0 $\mathrm{gkg}^{-1}$ (Sobulo and Osiname, 1981), 10-16 $\mathrm{mgkg}^{-1}$ (Adeoye and Agboola, 1985), 0.16-0.25 $\mathrm{cmolkg}^{-1}$ (Akinrinde and Obigbesan, 2000), 0.2-0.4 $\mathrm{cmolkg}^{-1}$ (Adeoye and Agboola, 1985) and $2.50 \mathrm{cmolkg}^{-1}$ (Akinrinde and Obigbesan, 2000) and 2-250 $\mathrm{mgkg}^{-1}$ (Alloway, 1995) respectively. The $\mathrm{Zn}$ and Fe were below the normal range of $1-90 \mathrm{mgkg}^{-1}$ (Alloway, 1995) and $2.50 \mathrm{mgkg}^{-1}$ (Rhue and Kidder, 1983) respectively.

Post-trial soil properties: The differences in soil $\mathrm{pH}$ between the polluted and unpolluted soils in both trials were significant (Table 3). The applied Cassava mill effluent caused a significant rise in the soil $\mathrm{pH}$ which tended towards neutral status. This increase in soil $\mathrm{pH}$ may definitely influence nutrient availability to plants. Similar increases in soil $\mathrm{pH}$ have earlier been reported by Ogboghodo et al. (2003) and Akpan et al. (2011). The organic carbon significantly increased with increased cassava mill effluent treatments in the trials (Table 3 ). The significant increase in organic carbon may be attributed to the decomposition of both dissolved and suspended particles. The increase in organic carbon has earlier been recorded by Orhue and Uzu (2011) in soils treated with Cassava mill effluent. The total $\mathrm{N}$ obtained in the trials increased with increased cassava mil effluent application (Table 3). The decomposition of the dissolved and suspended particles may be responsible for the increased $\mathrm{N}$. This result further confirmed earlier result of Akpan et al. (2011). The available $\mathrm{P}$ also significantly increased with increased cassava mill effluent application (Table 3). This report is similar to earlier results of Ogboghodo et al (2003) and Orhue and Uzu (2011) who reported a significant increase in available $\mathrm{P}$ in soils treated with Cassava mill effluent compared to unpolluted soils. The values of exchangeable $\mathrm{Ca}, \mathrm{Mg}, \mathrm{K}$ and $\mathrm{Na}$ at the end of the trials indicated that there were significant differences among the treatments including the control (Table 3). Indeed, the $\mathrm{Ca}, \mathrm{Mg}, \mathrm{K}$ and $\mathrm{Na}$ significantly increased with increased cassava mill effluent treatments. The increase in $\mathrm{Ca}, \mathrm{Mg}$ and $\mathrm{Na}$ may have accounted for the rise in soil $\mathrm{pH}$. However, the Exchangeable acidity (Ea) in the trials was significantly higher in the control than those treated with cassava mill effluent. The Ea decreased with increased effluent treatments. In both trials, the $\mathrm{Fe}, \mathrm{Cu}$ and $\mathrm{Zn}$ also significantly increased with increased cassava mill effluent (Table 3 ).

Influence of Cassava mill effluent on the nutrient content of fluted pumpkin: The influence of cassava mill effluent on the nutrient content of the fluted pumpkin is shown in table 4 . The $\mathrm{N}$ content of the plant decreased significantly with increased cassava mill effluent treatments (Table 4) whereas the $500 \mathrm{ml}$ and 200000 litres/ha in greenhouse and field trials respectively were significantly higher than other treatments in $\mathrm{P}$ and $\mathrm{K}$ components of the plant. This decrease in $\mathrm{N}$ content of the plant may be attributed to presence of immobilize soil $\mathrm{N}$ which although is not easily lost from the soil by leaching, volatilization, de-nitrification, it is not taken up by roots and micro-organisms as earlier reported by Foth (1990). Significantly higher $\mathrm{Mg}$ content of the plant was achieved by $300 \mathrm{ml}$ treatment in the greenhouse and 120000 litres/ha in the field trial compared to other treatments while the control treatment in both trials was significantly higher $(\mathrm{P}<0.05)$ than other treatments in $\mathrm{Na}$ component of the plant. Significantly higher Fe, $\mathrm{Cu}$ and $\mathrm{Zn}$ components of the plant were achieved in the cassava mill effluent treated plants in both trials compared to control. In the case of $\mathrm{Ca}$, the 0,100 and $500 \mathrm{ml}$ treatments were significantly higher than other treatments in the greenhouse trial whereas in the field trial all the treatments were not significantly different from one another.

Effect of Cassava mill effluent on height and number of leaves of fluted pumpkin: Table 5 shows the influence of Cassava mill effluent on the height and number of leaves of the plant. In the greenhouse trial, plant height significantly decreased with increasing Cassava mill effluent treatments whereas in the field, the 120000 litres/ha treatment was significantly higher than other treatments including control. Significantly higher number of leaves were obtained in $100 \mathrm{ml}$ treatment in the greenhouse and 120000 and 200000 litres/ha in the field trials compared to other treatments.

\section{Conclusion}

The results revealed that Cassava mill effluent increased the soil $\mathrm{pH}$, organic carbon, $\mathrm{N}, \mathrm{P}, \mathrm{K}, \mathrm{Mg}, \mathrm{Ca}, \mathrm{Na}, \mathrm{Fe}$, $\mathrm{Cu}$ and $\mathrm{Zn}$ components of the soil while the exchangeable acidity was depressed with increased Cassava mill 
effluent application. The increased soil $\mathrm{pH}$ indicated that Cassava mill effluent could be used as a source of liming in acid soils. With the exception of $\mathrm{N}$ and $\mathrm{Na}$, there was an improvement in the $\mathrm{P}, \mathrm{K}, \mathrm{Mg}, \mathrm{Ca}, \mathrm{Fe} . \mathrm{Cu}$ and $\mathrm{Zn}$ content of the plants treated with cassava mill effluent compared to control. The height of fluted pumpkin significantly decreased with increased cassava mill effluent treatment in the greenhouse trial whereas in the field trial, the 120000 and 200000 litres/ha were significantly higher $(\mathrm{P}<0.05)$ than other treatments. In the case of number of leaves, the $100 \mathrm{ml}$ treatment was significantly higher than other treatment in the greenhouse trial while the 120000 and 200000 litres /ha significantly dominated other treatments in the field trial. From the on-going result therefore it is suggested that Cassava mill effluent should be tried over the years in the cultivation of fluted pumpkin to ascertain the fertilizer potential.

\section{REFERENCES}

Ademoroti, C. M. A. (1996). Standard methods for water and effluent analysis $1^{\text {st }}$ edition, Foludex Press Ltd, Ibadan pp182

Adeoye, G. O. and Agboola, A. A. (1985). Critical levels of soil $\mathrm{pH}$, available $\mathrm{P}, \mathrm{K}, \mathrm{Zn}$ and $\mathrm{Mn}$ and maize ear leaf content of $\mathrm{P}, \mathrm{Cu}$ and $\mathrm{Mn}$ in sedimentary soil of Southwest Nigeria Fertilizer Research 6: 65- 71

Akinrinde, E. A. and Obigbesan, G. O. (2000). Evaluation of fertility status of selected soil for crop production in five ecological zones of Western Nigeria. Proceeding of the 26th Annual Conference of Soil Science Society of Nigeria. University of Ibadan. October 30- November 3. 279288.

Akpan, J. F., Solomon, M. G. and Bello, O. S. (2011). Effects of cassava mill effluent on some chemical and microbiological properties of soils in Cross River State, Nigeria. Global Journal of Agricultural Science 10 (2): 19-25

Alloway, B. I. (1995). Heavy metals in Soils $2^{\text {nd }}$ edition Halsted Press, John Wiley and Sons Inc, London

ANU (2007). New methods of cyanide removal to hold millions. Australia National University, Australia University Press Release. http//info.anu.edu.au/mac/media

Enwezor, W. O., Udo, E. J, Usoroh, N. J, Ayotade, K. A, Adepetu, J. A, Chude, V. O. and Udegbe, C. I. (1989). Fertilizer use and management practices for crops in Nigeria. Series No 2. Bobma Publishers Ibadan, Nigeria. pp163
FAO (2004). Strategic Environmental Assessment Food and Agricultural Organisation (FAO). http//www.fao.org/ docrep Retrieved on 23/11/2013

Foth, H. D. (1990). Fundamentals Soil Science. John Willey and Sons New York. pp360

Horsfall, M. J., Abia, A. A. and Spiff, A. I. (2006). Kinetic studies on the absorption of $\mathrm{Cd}^{2+}, \mathrm{Cu}^{2+}$ and $\mathrm{Zn}^{2+}$ ions from aqueous solution by cassava (Manihot esculentus Crantz) tuber bark waste. Bio resources Technology 97: 283-291.

IITA (1979). Selected methods for soil and plant analysis. International Institute of Tropical Agriculture, Manual Series No 1. pp70

Isabirye, M. G., Ruysschaert, L., Van-Linden, J. P., Maguada, M. K. and Deckers, J. (2007). Soil losses due to cassava and sweet potatoes harvesting: a case study from low input traditional agriculture. Soil Tillage Research 92: 96-103.

Jackson, M. L. (1962). Soil Chemical Analysis. Prentice Hall, New York pp263-268

Ogboghodo, I. A., Oluwafemi, A. P. and Unuigbe, C. A. (2003). Effects of polluting soil with cassava mill effluent on maize growth and some soil properties. Nigerian Journal of Applied Science 21: 44-49.

Olorunfemi, D. I., Emoefe, E. O. and Okieimen, F. E. (2008). Effect of cassava processing effluent on seedling height, biomass and chlorophyll content of some cereals. Research Journal of Environmental Sciences 2 (3): 221227.

Olorunfemi, D. I., Okoloko, G. E., Bakare, A. A and Akinboro, A. (2011). Cytotoxic and genotoxic effects of cassava effluents using the Allium cepa test. Research Journal of Mutagenesis, 1: 1-9

Orhue, E. R. and Uzu, F. (2011). Effect of cassava mill effluent on some physical and chemical properties of soils. Proceedings of the $35^{\text {th }}$ Annual Conference of the Soil Science Society of Nigeria $7^{\text {th }}-11^{\text {th }}$ March, 2011, Federal University Technology, Minna. 263-272

Payne, R. W. (2002). Genstat 6.1 manual VSN International Ltd. Oxford.

Rhue, R. D. and Kidder, G. (1983). Analytical procedures used by laboratory and the interpretation of results. Soil Science Department, University of Florida Gainsville. U.S.A.

Sobulo, R. A. and Osiname, O. A. (1981). Soils and fertilizer use in western Nigeria. Research Bulletin. No 11. I.A.R.T University of Ife.

Udo, E. J., Ibia, T. O., Ogunwale, J. A., Anuo, A. O. and Esu, I. E. (2009). Manual of soil, plant and water analysis. Sibon Books Ltd, Lagos, Nigeria. 